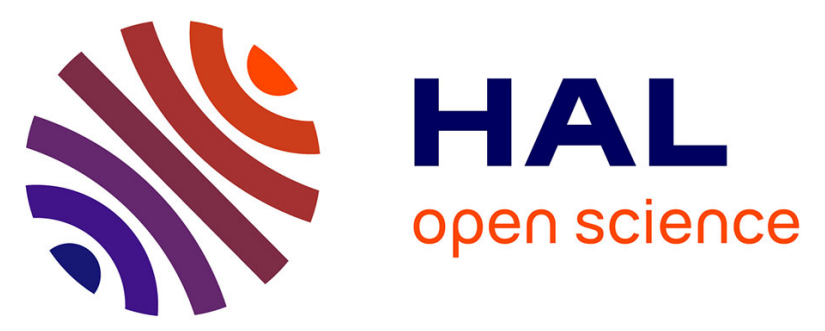

\title{
The adherence questionnaires in chronic inflammatory rheumatic diseases and their psychometric properties: a systematic literature review
}

\author{
Antsa Rakotozafiarison, Déborah Puyraimond-Zemmour, Xavier Romand, \\ Matthieu Lavielle, René-Marc Flipo, Christophe Richez, Alain Saraux, \\ Maxime Dougados, Laure Gossec, Anna Molto
}

\section{To cite this version:}

Antsa Rakotozafiarison, Déborah Puyraimond-Zemmour, Xavier Romand, Matthieu Lavielle, RenéMarc Flipo, et al.. The adherence questionnaires in chronic inflammatory rheumatic diseases and their psychometric properties: a systematic literature review. Joint Bone Spine, 2021, pp.105160. 10.1016/j.jbspin.2021.105160 . hal-03142841

\section{HAL Id: hal-03142841 https://hal.sorbonne-universite.fr/hal-03142841}

Submitted on 16 Feb 2021

HAL is a multi-disciplinary open access archive for the deposit and dissemination of scientific research documents, whether they are published or not. The documents may come from teaching and research institutions in France or abroad, or from public or private research centers.
L'archive ouverte pluridisciplinaire HAL, est destinée au dépôt et à la diffusion de documents scientifiques de niveau recherche, publiés ou non, émanant des établissements d'enseignement et de recherche français ou étrangers, des laboratoires publics ou privés. 
The adherence questionnaires in chronic inflammatory rheumatic diseases and their psychometric properties: a systematic literature review

Authors: Antsa Rakotozafiarison ${ }^{1 *}$, Déborah Puyraimond-Zemmour ${ }^{1,2^{*}}$, Xavier Romand ${ }^{3,4}$, Matthieu Lavielle ${ }^{5}$, Anna Moltó ${ }^{6,7}$, Rene-Marc Flipo ${ }^{8}$, Christophe Richez ${ }^{9,10}$, Alain Saraux ${ }^{11,12}$, Maxime Dougados ${ }^{6,7}$, Laure Gossec ${ }^{1,2}$

*The first 2 authors contributed equally.

\section{Affiliations}

1: Service de Rhumatologie, Hôpital de la Pitié Salpetrière, 48-83 Bd de 1'Hôpital 75013 Paris, France

2: Sorbonne Université, INSERM, Institut Pierre Louis d'Epidémiologie et de Santé Publique, 47-83 Bd Hopital, 75013 Paris, France

3: Univ. Grenoble Alpes, GREPI TIMC-IMAG, UMR 5525, 38000 Grenoble, France

4: Service de Rhumatologie, CHU Grenoble Alpes, 38000 Grenoble, France

5: Praticien privé, 419 Route du Médoc, 33520 Bruges, France

6: Service de Rhumatologie, Cochin Hospital, APHP, 75014 Paris, France

7: Université de Paris Inserm Unit 1183 (CRESS), 75014 Paris, France

8: Université de Lille, 42 Rue Paul Diez 59000 Lille, France

9: Service de Rhumatologie, Hôpital Pellegrin, 33000 Bordeaux, France

10: Université de Bordeaux, CNRS 5164, 33000 Bordeaux, France

11: Service de Rhumatologie, CHU de la Cavale-Blanche, boulevard Tanguy-Prigent, 29200 Brest, France

12: INSERM 1227, Université de Bretagne Occidentale, 29200 Brest, France

\section{Emails}

Déborah Puyraimond-Zemmour

deborah.puyraimondzemmour@aphp.fr

Xavier Romand

xromand@chu-grenoble.fr

Matthieu Lavielle

matthieu.lavielle@wanadoo.fr

Anna Molto

anna.molto@aphp.fr

Rene-Marc Flipo

rene-marc.flipo@chru-lille.fr

Christophe Richez

christophe.richez@chu-bordeaux.fr

Alain Saraux

alain.saraux@chu-brest.fr 
Maxime Dougados

Laure Gossec maxime.dougados@u-paris.fr

laure.gossec@aphp.fr

\section{Corresponding author:}

Dr Rakotozafiarison Antsa, Service de Rhumatologie, Hôpital de la Pitie Salpetrière, 48-83

Bd de 1'Hôpital 75013 Paris, France. rannintsoa@gmail.com

\section{Acknowledgments:}

This study was conducted thanks to an unrestricted grant from Abbvie France (Rencontres d'Experts en Rhumatologie program). AbbVie employees were present during the Rencontres d'Experts en Rhumatologie meetings, but did not influence the scientific discussions. AbbVie did not review the content or have influence on this letter.

The authors thank Margaux Orange for logistic assistance during the meetings and the 104 experts for input during the meeting.

\section{Disclosures of interest}

Maxime DOUGADOS has received honoraria from Abbvie for his participation as the convenor of this initiative. Xavier ROMAND, Déborah PUYRAIMOND-ZEMMOUR and Matthieu LAVIELLE have received honorarium fees from Abbvie for their participation as fellows of this initiative. All the other coauthors have received honoraria from Abbvie as members of the scientific committee. No other relevant disclosures.

Key words: patient adherence, compliance, questionnaires, rheumatoid arthritis, spondyloarthritis, inflammatory arthritis

Manuscript: 458 Words, 2 tables and 10 refs 


\section{Dear Sir,}

In chronic inflammatory rheumatic diseases (CIRDs) including rheumatoid arthritis (RA), spondyloarthritis (SpA), psoriatic arthritis (PsA), crystal-induced arthritis and connective tissue diseases (CTD), adherence to disease-modifying drugs is only moderate over the long term [1,2]. Insufficient patient adherence to treatments may lead to complications, unnecessary treatment switches, and increased costs [3]. Therefore, patient adherence to treatment should be assessed, however the optimal assessment method has not been determined [4].

The objective of this systematic literature review was to assess the psychometric properties of the main drug adherence questionnaires in patients with CIRDs.

In January 2019, a systematic literature review was performed in three databases (Pubmed, Cochrane central register of clinical trials, Embase) and several websites (Clinicaltrials.gov, World Health Organisation and the French High Authority of Health) as well as congress abstracts from the American and European congresses of the previous 3 years. The scope was limited to questionnaires published in English to assess adherence to drugs such as disease-modifying drugs, in CIRDs, i.e., RA, SpA, PsA, CTD, crystal-induced arthritis, vasculitis, and auto-inflammatory diseases [4, 5]. All questionnaires used to assess adherence were collected, then a specific search using the questionnaire name was carried out to obtain data on their psychometric properties according to the OMERACT filter [6]. We assessed overall validity, sensitivity (Se), specificity (Sp), internal consistency by Cronbach coefficient, reliability, and sensitivity to change. To summarise the data, and because a metaanalysis was not possible, properties are presented semi-quantitatively [6].

Of 1209 publications and 194 other documents, 242 papers reported adherence. Of these, 131 articles used questionnaires: 69/154 (44.8\%) in RA, $27 / 40$ (67.5\%) in systemic lupus erythematosus (SLE), 14/21 (66.6\%) in SpA, 9/16 (56.2\%) in PsA, 8/35 (22.8\%) in crystal-induced arthritis and 4/6 (66.6\%) in other CTD. Four questionnaires were used to evaluate drug adherence [7-10] (Table 1). The most used questionnaire was the MMAS (Morisky Medication Adherence Scale). The Compliance Questionnaire of Rheumatology (CQR) was validated in 85 patients with CIRD against as external standard with an electronic medication monitoring; the MASRI (Medication Adherence Self-report Inventory) was validated in 55 patients with SLE against adherence based on pharmacy refill information. The MMAS was validated in 91 patients with gout against medication possession ratio and 
the MARS (Medication Adherence Report Scale) in 108 patients with RA. Reproducibility was correct; some questionnaires are subject to copyright (Table 2).

Our results indicate that four questionnaires are being used to measure medication non-adherence in CIRDs; the most used is the MMAS which is unfortunately copyrighted and not fully validated in rheumatology. The CQR and MASRI questionnaires were the mostextensively validated in rheumatology, but the CQR is long and the MASRI only used for SLE. Thus it appears that to date, a simple, reliable and valid questionnaire to assess drug adherence is lacking.

\section{References:}

[1] Van den Bemt, Zwikker HE, CHM Van den Ende. Medication adherence in patients with rheumatoid arthritis: a critical appraisal of the existing literature. Expert Rev Clin Immunol. 2012;8(4):337-51.

[2] Beauvais C, Pau C, Hautin-Monteil V, Ducrot MC, Veerabudun K, Flipo RM. One-third of patients are low-adherent to methotrexate for rheumatoid arthritis at the initiation of a first biologic. A cross-sectional study investigating adherence rate and factors. JBS, 2020, 87, 6689-

[3] Pasma A, Schenk C, Timman R et al. Does non-adherence to DMARDs influence hospital-related healthcare costs for early arthritis in the first year of treatment? PloS One. 2017 (12), p. e0171070.

[4] Gossec L, Molto A, Romand X et al. Recommendations for the assessment and optimization of adherence to disease-modifying drugs in chronic inflammatory rheumatic diseases: A process based on literature reviews and expert consensus JBS 2019; 86(1):13-9.

[5] Lavielle M, Puyraimond-Zemmour D, Romand X et al. Methods to improve medication adherence in patients with chronic inflammatory rheumatic diseases: a systematic literature review. RMD Open 2018;4(2):e000684.

[6] Boers M, Kirwan JR, Wells G. Developing core outcome measurement sets for clinical trials: OMERACT filter 2.0. J Clin Epidemiol. 2014;67(7):745-53.

[7] Klerk E, Van der Heijde D, Landewé R, Van der Tempel H, Van der Linden S. The compliance-questionnaire-rheumatology compared with electronic medication event monitoring: a validation study. J Rheumatol. 2003;30(11):2469-75.

[8] Thompson K, Kulkarni J, Sergejew AA. Reliability and validity of a new Medication Adherence Rating Scale (MARS) for the psychoses. Schizophr Res. 2000;42(3):241-7. doi: 10.1016/s0920-9964(99)00130-9. 
[9] Walsh JC, Mandalia S, Gazzard B G. Responses to a 1 month self-report on adherence to antiretroviral therapy are consistent with electronic data and virological treatment outcome. AIDS. 2002 Jan 25;16(2):269-77.

[10] Morisky DE, Ang A, Krousel-Wood M, Ward HJ. Predictive validity of a medication adherence measure in an outpatient setting. J Clin Hypertens (Greenwich). 2008;10(5):34854.

Table 1. Questionnaires used to evaluate drug adherence in recently published studies

\begin{tabular}{|c|c|c|c|c|c|c|}
\hline & $\mathbf{R A}$ & SpA & Lupus & PsA & $\begin{array}{c}\text { Cristal } \\
\text { induced } \\
\text { arthritis }\end{array}$ & $\begin{array}{c}\text { Vasculitis } \\
\text { and auto- } \\
\text { inflammatory } \\
\text { diseases }\end{array}$ \\
\hline $\begin{array}{l}\text { Total number } \\
\text { of studies }\end{array}$ & 154 & 21 & 40 & 16 & 35 & 6 \\
\hline $\begin{array}{l}\text { Number of } \\
\text { articles using } \\
\text { adherence } \\
\text { questionnaires }\end{array}$ & $69(44.8 \%)$ & $14(66.6 \%)$ & $27(67.5 \%)$ & $9(56.2 \%)$ & $8(22.8 \%)$ & $4(66,6 \%)$ \\
\hline $\begin{array}{l}\text { Number of } \\
\text { questionnaires }\end{array}$ & 3 & 3 & 3 & 3 & 3 & 2 \\
\hline $\begin{array}{l}\text { Most used } \\
\text { questionnaire }\end{array}$ & CQR & MMAS & MMAS & MMAS & MMAS & MMAS \\
\hline $\begin{array}{l}\text { Other } \\
\text { questionnaires } \\
\text { used }\end{array}$ & $\begin{array}{l}\text { MMAS, } \\
\text { MARS }\end{array}$ & $\begin{array}{l}\text { CQR, } \\
\text { MARS }\end{array}$ & $\begin{array}{c}\text { CQR, } \\
\text { MASRI }\end{array}$ & $\begin{array}{c}\text { CQR, } \\
\text { MARS }\end{array}$ & $\begin{array}{c}\text { MARS, } \\
\text { CQR }\end{array}$ & CQR \\
\hline
\end{tabular}

MMAS: Morisky Medication Adherence Scale; MASRI: Medication Adherence Self-Report Inventory; MARS: Medication Adherence Report Scale; CQR: Compliance Questionnaire of Rheumatology 
Table 2. Questionnaires performances to assess adherence in chronic inflammatory rheumatic diseases

\begin{tabular}{|c|c|c|c|c|}
\hline & $\begin{array}{c}\text { Compliance } \\
\text { Questionnaire of } \\
\text { Rheumatology: } \\
\text { CQR-19/5 }\end{array}$ & $\begin{array}{c}\text { Medication } \\
\text { Adherence } \\
\text { Report Scale: } \\
\text { MARS10/9RA/6/ } \\
8 \\
5 / 4\end{array}$ & $\begin{array}{l}\text { Medication } \\
\text { Adherence } \\
\text { Self-report } \\
\text { Inventory: } \\
\text { MASRI }\end{array}$ & $\begin{array}{c}\text { Morisky } \\
\text { Medication } \\
\text { Adherence } \\
\text { Scale: } \\
\text { MMAS-8/4 }\end{array}$ \\
\hline $\begin{array}{l}\text { N studies on the } \\
\text { questionnaire }\end{array}$ & 48 & 13 & 7 & 62 \\
\hline Copyright & No & No & Yes & Yes \\
\hline Reproducibility & $\begin{array}{c}++ \\
\text { Cc: } 0.630\end{array}$ & $\begin{array}{c}++ \\
\text { Ratio: } 0.65\end{array}$ & $\begin{array}{c}+++ \\
\text { kappa: } 0.54\end{array}$ & $\begin{array}{c}++ \\
\text { kappa: } 0.19\end{array}$ \\
\hline $\begin{array}{l}\text { Validity assessed in } \\
\text { rheumatology }\end{array}$ & Yes* & No & Yes** & $+1-$ \\
\hline $\mathrm{Se} / \mathrm{Sp}(\%)$ & $62-98 / 67-97$ & $13-53 / 57-94$ & $87 / 86$ & $81-93 / 44-53$ \\
\hline Internal consistency & $0.71-0.85$ & $0.60-0.75$ & 0.70 & 0.54 \\
\hline Feasibility & $+/+++$ & +++ & +++ & +++ \\
\hline
\end{tabular}

Cc: Correlation Coefficient, Se: sensitivity, Sp: specificity

CQR: adequate test-retest; MARS: good test-retest; MMAS: slight concordance at test-retest The + represents a semi-quantitative summary of the available literature with more + meaning higher/better results (from - to +++).

* Electronic medication monitoring

**Adherence based on pharmacy refill information 